\section{Animal Health Research Reviews}

Published in collaboration with the Conference of Research Workers in Animal Diseases

\section{Editor-in-Chief}

C. Gyles, University of Guelph, Canada

Animal Health Research Reviews provides an international forum for the publication of reviews and commentaries on all aspects of animal health. Papers include in-depth analyses and broader overviews of all facets of health and science in both domestic and wild animals. Major subject areas include physiology and pharmacology, parasitology, bacteriology, food and environmental safety, epidemiology and virology. The journal will be of interest to researchers involved in animal health, parasitologists, food safety experts and academics interested in all aspects of animal production and welfare.

\section{For free online content visit: http://journals.cambridge.org/ahrsample}

\section{Free email alerts}

Keep up-to-date with new content http://journals.cambridge.org/ahr-alerts

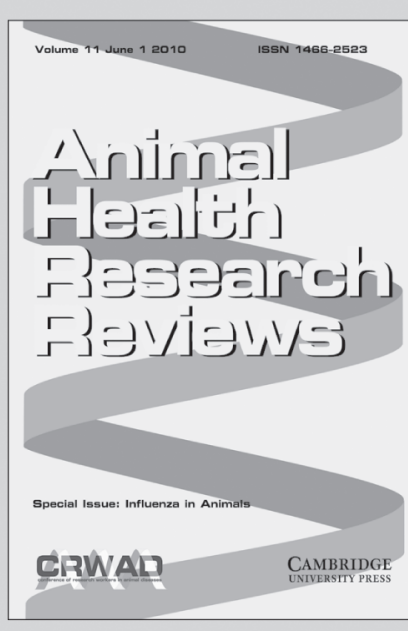

Animal Health Research Reviews is available online at: http://journals. cambridge.org/ahr

To subscribe contact Customer Services

\section{Americas:}

Phone +1 (845) 3537500

$\mathrm{Fax}+1$ (845) 3534141

Email

subscriptions_newyork@cambridge.org

\section{Rest of world:}

Phone +44(0)1223 326070

$\mathrm{Fax}+44(0) 1223325150$

Email journals@cambridge.org

\section{Price Information}

is available at:

http://journals.cambridge.org/ahr 


\section{CAMBRIDGE JOURNALS}

\section{Journal of Dairy Research}

Published for the Institute of Food Research and the Hannah Research Institute

\section{Executive Editors}

D. G. Chamberlain, Hannah Research Institute, UK

E. C. Needs, Hannah Research Institute, UK

Journal of Dairy Research publishes original scientific research on all aspects of mammary biology and dairy science including: the physiology, biochemistry, cell biology and endocrinology of lactation; animal husbandry, milk production, composition, preservation, processing and separation; biotechnology and food science; properties of milk proteins and other components; dairy products such as cheese, fermented milks and spreads; relevant studies in bacteriology, enzymology and immunology, the use of milk products in other foods; and the development of methods relevant to these subjects.

Price information is available at: http://journals.cambridge.org/dar

\section{Free email alerts}

Keep up-to-date with new material - sign up at http://journals.cambridge.org/dar-alerts

Journal of Dairy Research is available online at: http://journals.cambridge.org/dar

To subscribe contact Customer Services

\section{in Cambridge:}

Phone +44 (0)1223 326070

$\mathrm{Fax}+44$ (0)1223 325150

Email journals@cambridge.org

\section{in New York:}

Phone +1 (845) 3537500

$\mathrm{Fax}+1$ (845) 3534141

Email

subscriptions_newyork@cambridge.org 


\section{Epidemiology and Infection}

\section{Editor-in-Chief}

Norman Noah, London School of Hygiene and Tropical Medicine, UK

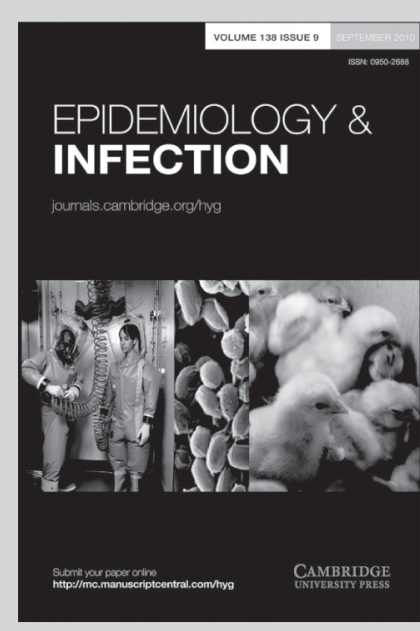

Epidemiology and Infection is available online at: http://journals.cambridge.org/hyg

To subscribe contact Customer Services

in Cambridge:

Phone $+44(0) 1223326070$

$\mathrm{Fax}+44(0) 1223325150$

Email journals@cambridge.org

\section{in New York:}

Phone +1 (845) 3537500

$\mathrm{Fax}+1$ (845) 3534141

Email

subscriptions_newyork@cambridge.org

\section{Price information}

is available at: http://journals.cambridge.org/hyg

\section{Free email alerts}

Keep up-to-date with new material - sign up at http://journals.cambridge.org/alerts 


\section{CAMBRIDGE JDURNALS}

Journal of
Helminthology

Editor

John Lewis, Royal Holloway, University of London, UK

Journal of Helminthology publishes original papers and review articles on all aspects of pure and applied helminthology, particularly those helminth parasites of environmental health, medical or veterinary importance. Research papers on helminths in wildlife hosts, including plant and insect parasites, are also published along with taxonomic papers contributing to the systematics of a group. The journal will be of interest to academics and researchers involved in the fields of human and veterinary parasitology, public health, microbiology, ecology, epidemiology and biochemistry.

\section{Price information}

is available at: http://journals.cambridge.org/jhl

\section{Free email alerts}

Keep up-to-date with new material - sign up at http://journals.cambridge.org/jhl-alerts

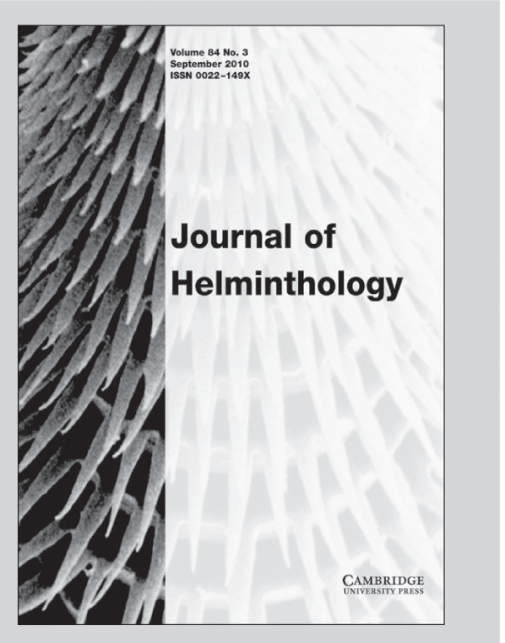

Journal of Helminthology is available online at: http://journals.cambridge.org/jhl

To subscribe contact Customer Services

in Cambridge:

Phone $+44(0) 1223326070$

$\mathrm{Fax}+44(0) 1223325150$

Email journals@cambridge.org

in New York:

Phone +1 (845) 3537500

$\mathrm{Fax}+1(845) 3534141$

Email

subscriptions_newyork@cambridge.org 


\section{CAMBRIDGE JUURALS}

\section{The Lichenologist}

Published on behalf of The British Lichen Society

\section{Senior Editor}

Peter D. Crittenden, University of Nottingham, UK

The Lichenologist is the premier scientific journal devoted exclusively to the study of lichens worldwide. As the leading forum for the dissemination of new concepts and topical reviews, The Lichenologist reaches more scientists concerned with the study of lichens and lichen symbionts than any other single journal. All aspects of lichenology are considered including systematics and phylogenetics; molecular biology; ultrastructure, anatomy and morphology; secondary chemistry, effects of pollutants and use as bioindicators; biogeography.

\section{Price information}

is available at: http://journals.cambridge.org/lic

\section{Free email alerts}

Keep up-to-date with new material - sign up at http://journals.cambridge.org/lic-alerts

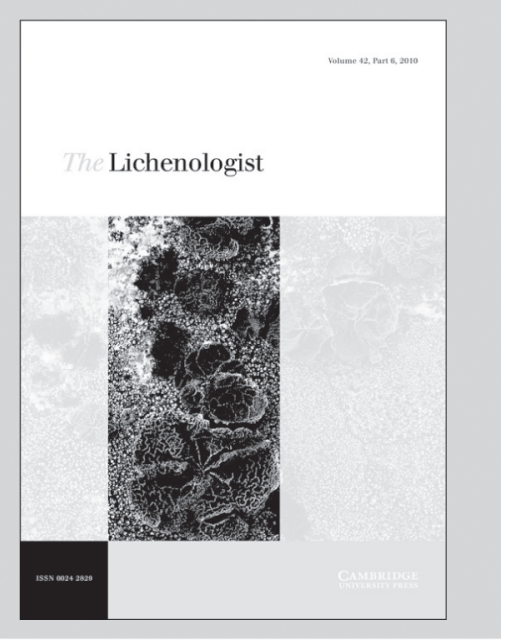

The Lichenologist

is available online at: http://journals. cambridge.org/lic

To subscribe contact Customer Services

in Cambridge:

Phone +44 (0)1223 326070

$\mathrm{Fax}+44(0) 1223325150$

Email journals@cambridge.org

in New York:

Phone +1 (845) 3537500

$\mathrm{Fax}+1$ (845) 3534141

Email

subscriptions_newyork@cambridge.org 


\section{CAMBRIDGE JOURNALS}

\section{Microscopy and Microanalysis}

Published for the Microscopy Society of America

\section{Editor}

Robert L. Price, University of South Carolina, USA

Microscopy and Microanalysis, a peer-reviewed bimonthly, publishes original research papers in the fields of microscopy, imaging, and compositional analysis. This distinguished international forum is intended for microscopists in both biology and materials science. The journal provides significant articles that describe new and existing techniques and instrumentation, as well as the applications of these to the imaging and analysis of microstructure. Microscopy and Microanalysis also includes review articles, short communications, letters to the editor, and book reviews.

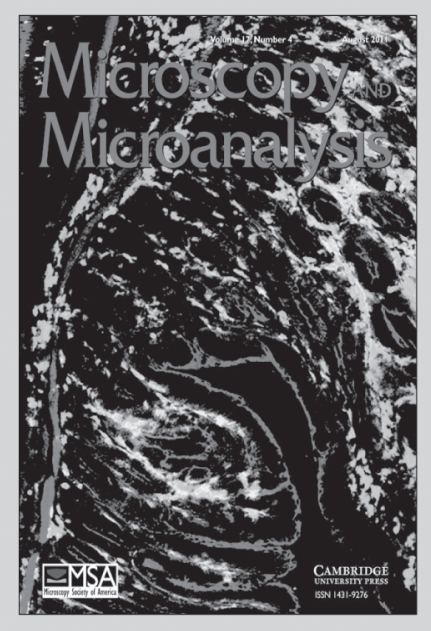

Microscopy and Microanalysis is available online at: http://journals.cambridge.org/mam

To subscribe contact Customer Services

\section{in Cambridge:}

Phone +44 (0)1223 326070

$\mathrm{Fax}+44(0) 1223325150$

Email journals@cambridge.org

in New York:

Phone +1 (845) 3537500

Fax +1 (845) 3534141

Email

subscriptions_newyork@cambridge.org

Free email alerts

Keep up-to-date with new material - sign up at

journals.cambridge.org/register 


\section{Journal of Tropical Ecology}

Editor

Ian Turner, Winchelsea, UK

Journal of Tropical Ecology publishes papers in the important and now established field of the ecology of tropical regions, either arising from original research (experimental or descriptive) or forming significant reviews. First published in 1985, Journal of Tropical Ecology has become a major international ecological journal. With clear, stimulating and readable reports of recent research findings, the journal provides a platform for the dissemination of information on all aspects of tropical communities and ecosystems

\section{Price information}

is available at: http://journals.cambridge.org/tro

\section{Free email alerts}

Keep up-to-date with new material - sign up at http://journals.cambridge.org/tro-alerts

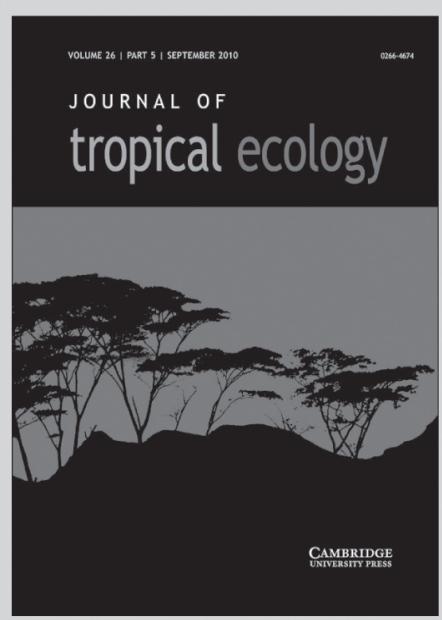

Journal of Tropical Ecology

is available online at:

http://journals.cambridge.org/tro

To subscribe contact

Customer Services

in Cambridge:

Phone $+44(0) 1223326070$

Fax +44 (0)1223 325150

Email journals@cambridge.org

in New York:

Phone +1 (845) 3537500

$\mathrm{Fax}+1(845) 3534141$

Email

subscriptions_newyork@cambridge.org

For free online content visit: http://journals.cambridge.org/tro
CAMBRIDGE UNIVERSITY PRESS 


\section{Parasitology}

Back volumes. Vols. 1-71: Inquiries should be addressed to Wm. Dawson \& Sons Ltd, Cannon House, Folkestone, Kent. Vols. 72 onwards: quotations for parts still in print may be obtained from Cambridge or the American Branch of Cambridge University Press.

Copying. This journal is registered with the Copyright Clearance Center, 222 Rosewood Drive, Danvers, MA 01923, USA. Organizations in the USA who are also registered with C.C.C. may therefore copy material (beyond the limits permitted by sections 107 and 108 of US copyright law) subject to payment to C.C.C. of the per-copy fee of $\$ 16.00$. This consent does not extend to multiple copying for promotional or commercial purposes. Code 0031-1820/2012\$16.00.

Organizations authorized by the Copyright Licensing Agency may also copy material subject to the usual conditions.

ISI Tear Sheet Service. 3501 Market Street, Philadelphia, Pennsylvania 19104, USA, is authorized to supply single copies of separate articles for private use only.

For all other use, permission should be sought from Cambridge or the American Branch of Cambridge University Press.

Claims for missing issues can only be considered if made immediately after receipt of the subsequent issue.

Advertising. Details of advertising in Parasitology may be obtained from the publisher.

Online submission. Authors are encouraged to submit their manuscripts online. Go to http:// mc.manuscriptcentral.com/par/ to open an author's account for Parasitology. Manuscript Central is helping to improve the speed of the publication process for the journal.

Front Cover illustration: Red-stained Toxoplasma gondii tachyzoites in the lamina propria of mouse ileum (left) and at higher power in a villus (right). (Photography by Dr El Bissati.) From Dubey et al. Vol. 139 (1) pp. 1-13.

(C) Cambridge University Press 2012

The Edinburgh Building, Cambridge CB2 8RU, United Kingdom

32 Avenue of The Americas, New York, NY 10013-2473, USA

477 Williamstown Road, Port Melbourne, VIC 3207, Australia

C/ Orense, 4, Planta 1328020 Madrid, Spain

Lower Ground Floor, Nautica Building, The Water Club, Beach Road,

Granger Bay, 8005 Cape Town, South Africa 


\section{PARASITOLOGY}

\section{CONTENTS}

\section{REVIEW ARTICLES}

Toxoplasma gondii infection in pregnant women in China X.-J. Gao, Z.-J. Zhao, Z.-H. He, T. Wang, T.-B. Yang, X.-G. Chen, J.-L. Shen, Y. Wang, F.-L. Lv, G. Hide and Z.-R. Lun

An assessment of the use of drug and non-drug interventions in the treatment of Ichthyophthirius multifiliis Fouquet, 1876, a protozoan parasite of freshwater fish S. M. Picón-Camacho, M. Marcos-Lopez, J. E. Bron and A. P. Shinn

\section{RESEARCH ARTICLES}

In vitro and in vivo behaviour of sympatric Leishmania (V.) braziliensis, L. (V.) peruviana and their hybrids Sofia Cortes, Carina Esteves, Isabel Maurício, Carla Maia, José Manuel Cristovão, Michael Miles and Lenea Campino

Leishmania (Viannia) braziliensis: insights on subcellular distribution and biochemical properties of heparin-binding proteins

Luzia Monteiro De Castro Côrtes, Mirian Claudia De Souza Pereira, Francisco Odêncio Rodrigues De Oliveira Junior, Suzana Corte-Real, Franklin Souza Da Silva, Bernardo Acácio Santini Pereira, Maria De Fátima Madeira, Marcia Terezinha Baroni De Moraes, Reginaldo Peçanha Brazil and Carlos Roberto Alves

The adaptive potential of a survival artist: characterization of the in vitro interactions of Toxoplasma gondii tachyzoites with di-cationic compounds in human fibroblast cell cultures Christian Kropf, Karim Debache, Christoph Rampa, Fabienne Barna, Michelle Schorer, Chad E. Stephens, Mohamed A. Ismail, David W. Boykin and Andrew Hemphill

Diversity and distribution of avian haematozoan parasites in the western Indian Ocean region: a molecular survey

Farah Ishtiaq, Jon S. Beadell, Ben H. Warren

and Robert C. Fleischer
NTPDase activity in lymphocytes of rats infected by Trypanosoma evansi

Camila B. Oliveira, Aleksandro S. Da Silva, Viviane C. G. Souza,

Marcio M. Costa, Jeandre A. S. Jaques, Daniela B.R Leal,

Sonia T. A. Lopes and Silvia G. Monteiro

Anticoccidial activity of herbal complex in broiler chickens challenged with Eimeria tenella

Muhammad A. Zaman, Zafar labal, Rao Z. Abbas and

Muhammad N. Khan

Delayed tail loss during the invasion of mouse skin by cercariae of Schistosoma japonicum

Ting Wang, Zheng-Ming Fang, Jia-Hui Lei, Fei Guan, Wen-Qi Liu, Ann Bartlett, Phil Whitfield and Yong-Long Li

Identification of field-caught Culicoides biting midges using matrix-assisted laser desorption/ionization time of flight mass spectrometry

Christian Kaufmann, Francis Schaffner, Dominik Ziegler,

Valentin Pflüger and Alexander Mathis

Natural occurrence of lethal aspergillosis in the cattle tick Rhipicephalus (Boophilus) microplus (Acari: Ixodidae) E. Miranda-Miranda, R. Cossio-Bayugar, F. Martínez-lbañez,

R. Casasanero-Orduña and J. Folch-Mallo

Adaptive timing of detachment in a tick parasitizing hole-nesting birds

J. White, D. J. A. Heylen and E. Matthysen

Phagocyte-specific S100 proteins in the local response to the Echinococcus granulosus larva

Tatiana Basika, Natalia Muñoz, Cecilia Casaravilla, Florencia Irigoín, Carlos Batthyány, Mariana Bonilla, Gustavo Salinas, José Pedro Pacheco, Johaness Roth, Rosario Durán and Alvaro Díaz 